\title{
JEWISH GENDER STUDIES AND CONTEMPORARY LITERARY CRITICISM
}

\author{
Ruth Gilbert*
}

\begin{abstract}
My starting point for this discussion is my work in literary criticism, especially in terms of my ongoing research which focuses on contemporary British Jewish writing. So, drawing from a contemporary cultural context, in the following, I situate gender studies in relation to the ways in which it impacts on readings of recent Jewish literature. Rather than trying to sum up five decades of thinking about gender, I suggest a few moments in the development of gender studies, in terms of some of the achievements, challenges and changes we have seen since the 1970s; and then, in brief, I look forward to future developments.
\end{abstract}

\section{Theoretical Contexts}

Firstly, I want to give a broad overview of some theoretical contexts and then look at the ways in which ideas about Jewishness have intersected with those developments. Literary criticism is of course informed by wider intellectual, social and cultural movements. So, in line with other disciplinary approaches, I begin with an understanding of gender as focused on the construction and representation of categories of masculinity and femininity.

In terms of the evolution of the kinds of gender studies that are applied within literary criticism today, we need to situate developments from the early contexts of Second Wave feminism and its impact in the academy during the 1970s and 1980s. Alongside a new emphasis on women's experience within literature and criticism, which was formative throughout the 1980s and 1990s, feminism has to some extent evolved into what we now think of as gender studies. That is to say that the construction of masculinity, as a social and cultural category, has, alongside the study of femininity, also become a significant focus of enquiry.

In recent years gender studies has further evolved to incorporate a far wider exploration of sexual identification. Within the contemporary social context, as well as within academic discourse, there are now many and various non-binary permutations of gender, sex and sexuality. In terms of literary theory, the inception of queer theory has been pivotal within this development and has shaped much current critical thinking in cultural and literary studies. Most notably, the work of the philosopher and theorist, Judith Butler, in the 1990s, particularly her exploration of gender performativity, was groundbreaking.' Alongside other theorists of the time, such as the literary critic Eve Kosofsky Sedgwick, this work transformed the field. ${ }^{2}$ As Sedgwick and her contemporaries argued at the time, queer theory allows for a multiple and diffuse understanding of identities. In a defining statement she explained that:

[Queer] is the open mesh of possibilities, gaps, overlaps, dissonances and resonances, lapses and excesses of meaning when the constituent elements of anyone's gender, of anyone's sexuality aren't made (or can't be made) to signify monolithically'.

These influential academic considerations arguably prefigured some of the more mainstream social and cultural developments that we see today.

\footnotetext{
* Reader in the Department of English, Creative Writing and American Studies, University of Winchester, Winchester, UK. Email: ruth.gilbert@winchester.ac.uk

'Judith Butler, Gender Trouble (London: Routledge, 1990); Bodies That Matter (London: Routledge, 1993).

${ }^{2}$ Eve Kosofsky Sedgwick, Between Men (New York: Columbia, 1985); Epistemology of the Closet (Berkeley: University of California Press, 1990); Tendencies (London: Routledge, 1994).

${ }^{3}$ Sedgwick, Tendencies, 8.
} 
In terms of the particularly Jewish focus of this contribution, it is interesting to explore how a queer potential for destabilisation and multiplicity, with regard to categories of sex, gender and sexual identification, intersects with conceptualisations of Jewishness. Both Butler and Sedgwick originate from Jewish backgrounds and this is perhaps not entirely coincidental. With its interest in "possibilities, gaps, overlaps, dissonances and resonances", queer theory is a methodology that can be applied within and beyond gender studies and I would suggest that it also underlies many developments in cultural Jewish studies of recent decades. So, what is it that makes it possible to read Jewishness alongside queerness and how does this strategy inform developments within contemporary Jewish literary studies?

An example of the influence of such thinking might be seen in the work of Daniel Boyarin, whose work on Jewish masculinity in the 1990s is significant in developing the connection between the ways in which both gender and Jewishness are constructed within fundamentally unstable cultural categories. ${ }^{4}$ In an important 2003 edited volume, Queer Theory and the Jewish Question, Boyarin, along with his co-editors, explains that the aim of the collection is to look at "rhetorical and theoretical connections" in order to explore how "Jewishness and queerness... are bound up with one another in particularly resonant ways."

The uncertainty that has characterised historical attempts to categorise Jewishness is one particular point of resonance with queer theory. Here the work of Sander Gilman on the Jewish body, focusing often on nineteenth and early twentieth-century European conceptualisations of gender, sex and Jewishness has been central in shaping the field. Similarly, the literary critic Bryan Cheyette has argued, in a persuasive body of work, that Jewishness has historically been constructed within British culture as a profoundly ambiguous signifier of difference. As Cheyette explains, within late nineteenthcentury and modernist discourses, the "Jew" was figured as a confusing embodiment of indeterminacy and this effect has, to some extent, lingered. ${ }^{6}$ Cheyette's work, first published in the 1990s, has been vital in developing the field of Jewish literary studies, especially within the British context. Cheyette's critical contribution has also encouraged a new generation of literary critics whose work explores relationships between Jewishness, gender and sexuality, alongside intersecting identifications such as nationality, race and ethnicity. These include academics whose work focuses on gender and sexuality, such as Nadia Valman, who has looked particularly at the construction of the "Jewess" within nineteenth-century literature; and David Brauner, who has written extensively about both male and female Jewish authors.

\section{Textual Tendencies}

Literature, I would argue, is a particularly dynamic way of exploring attitudes towards gender and sexuality and cultural representations can construct as well as represent trends, tensions and anxieties. Clearly there is much to say on this subject and there have been many interesting studies of the ways in which gender informs the writing and reading of contemporary Jewish literature and cultural representation more generally. A fuller account of the field would need to consider, amongst other matters, the relationships between gender and genre in literary works. But for now, I want to indicate in brief some of the ways that gender has been depicted and interrogated within Jewish writing of recent decades.

Stereotypes of Jewish masculinity, ranging from the "Jew-devil" of early modern literature, to the pathologised Jew of modernity, the "muscle Jew" of Zionist ideology, and the anxious Jew of American comedy, have all been the focus of critical interrogation in recent years. In Unheroic Conduct (1997), Daniel Boyarin starts from the premise that Jewish men are routinely viewed in terms of

\footnotetext{
${ }^{4}$ Daniel Boyarin, Unheroic Conduct: The Rise of Heterosexuality and the Invention of the Jewish Man (Berkeley: University of California Press, 1997).

Daniel Boyarin, Daniel Itzkovitz and Ann Pellegrini, eds., Queer Theory and The Jewish Question (New York: Columbia UP, 2003), 1 .

${ }^{6}$ Bryan Cheyette, Constructions of 'The Jew' in English Literature and Society (Cambridge: CUP, 1993); Between 'Race' and Culture: Representations of 'The Jew' (Stanford: Stanford UP, 1996).
} 
effeminacy. Rather than attempting to dispel this stereotype, Boyarin turns instead to the premodern rabbinical tradition as a way of "revalorizing and reeroticizing" the Jewish male "sissy". This argument is suggestive, and forms part of a current interest in rethinking the ways in which Jewish masculinities have been constructed both in the past and in the present.

The depiction of characters as diverse as Shylock, Fagin, Daniel Deronda and Leopold Bloom, demonstrate some of the ways in which English literature has been intrigued and somewhat unsettled by Jewish masculinity. Throughout this history, the Jewish man has been presented as both asexual and hyper-sexual, both weakly passive and dangerously predatory, effeminised and grossly monstrous. The Jewish man is, in these terms, an ambiguous, overdetermined and shifting signifier. Historically, the Jewish body, which could be seen to straddle a boundary between black and white, masculine and feminine, excess and lack, was, as much of Sander Gilman's work has demonstrated, a signifier that both challenged and assisted differentiation. ${ }^{8}$ As James Shapiro explains, in the context of early modern representation, "when it came to Jews, the boundaries between male and female were often seen as quite slippery."

So, with this complex background in mind, we see that in recent years, and especially since the 1970s, although the "tough Jew" is a potent image in reconfiguring Jewish masculinity, it is not the only way that Jewish masculinity has been represented within contemporary culture. ${ }^{10}$ It coexists alongside other equally pervasive images, such as that of the neurotic Jewish man, popularised by, for example, Woody Allen in film; a trope that is played with by someone like the comedian Simon Amstell or the film maker Josh Appignanesi in Britain. Certainly, contemporary fiction by Philip Roth, Howard Jacobson, Clive Sinclair and younger writers such as Michael Chabon, Shalom Auslander, Jonathan Safran Foer and Adam Thirlwell, amongst many others, takes existing stereotypes of Jewish masculinity as its starting point and, to varying degrees, then subverts and expands ideas about contemporary Jewish masculinities.

The historical representation of Jewish women demonstrates that stereotypes relating to Jewish women are as charged and as contradictory as those relating to Jewish men, and perhaps even more so. The Jewish woman has been both celebrated and vilified. In this respect, one might note that in this way she is no different from women in Western culture in general. However, depictions of Jewish femininity are inflected by some rather specific concerns. From the matriarchs, temptresses and warrior women of the Old Testament to the suffocating Jewish mothers and spoiled Jewish princesses of contemporary representation, Jewish women have been constructed in a variety of compelling yet contrary ways. Historically, and perhaps even currently, the "Jewess", embodies a series of contradictory signifiers and these cannot be easily contained.

Works written by established novelists in the US, such as Cynthia Ozick, Rebecca Goldstein and Allegra Goodman, and younger authors such as Nicola Krauss, have contributed significantly to developments in Jewish women's writing. Arguably, the American context has, in general, fostered a more confident Jewish presence. However, within the UK, popular awareness of British-Jewish women writers in recent years has increased as a result of high profile work by writers such as Linda Grant, Naomi Alderman and Charlotte Mendelson. For example, Alderman's 2006 Orange-prize winning novel Disobedience and Mendelson's When We Were Bad (2007) generated a sense of growing visibility in the representation of British-Jewish women." More recently, novels by Eve Harris and Francesca Segal have extended this sense of opening up the experience of the British Jewish community

\footnotetext{
${ }^{7}$ Boyarin, Queer Theory, 19.

${ }^{8}$ Sander Gilman, The Jew's Body (Abingdon: Routledge, 1992), 39.

${ }^{9}$ James Shapiro, Shakespeare and the Jews (New York: Colombia University Press, 1996), 38.

${ }^{10}$ For work on Jewish masculinity see Todd Presner, Muscular Judaism: The Jewish Body and the Politics of Regeneration (London: Routledge, 2007); Harry Brod, ed., A Mensch Among Men: Explorations in Jewish Masculinity (Freedom: Crossing Press, 1988); Harry Brod and Rabbi Shaw Israel Zevit, eds., Brother Keepers: New Perspectives on Jewish Masculinity (Harriman: Men's Studies Press, 2010).

${ }^{11}$ Naomi Alderman, Disobedience (London: Viking, 2006); Charlotte Mendelson, When We Were Bad(London: Picador, 2007).
} 
to a wider audience..$^{12}$ These literary texts take gender as a starting point, exploring tensions and possibilities as they situate issues of domesticity, religious belief and self-actualisation alongside increasingly postmodern reconfigurations of gender and sexual identifications.

\section{Future Directions}

So, looking forward, it seems clear that gender studies, in terms of its impact on Jewish cultural studies, is in a process of ongoing evolution. In literary terms, hybrid forms of cultural representation, such as the work of graphic novelist Sarah Lightman who creates confessional and personal comic book art about gender, faith and Jewish identity, points to the ways in which gender studies intersects with Jewish studies in ways that are continuing to shape the field. ${ }^{13}$

Moreover, in a time in which television box sets intersect with more traditional text-based forms of story-telling, it seems right to end with a few words on the recent television, Transparent. ${ }^{14}$ Written and directed by Jill Soloway, this study of a contemporary American Jewish family, in which a middle-aged, liberal, academic father comes out as transgender, raises many questions. As Soloway has put it, "the words male and female describe who we used to be". ${ }^{15}$ However, Transparent's deconstruction of gender is perhaps just the starting point for an interrogation of identifications across a range of categories. The programme, first broadcast in 2014 and in the most recent series to date (2017), presents a cumulative and subtle exploration of gender, sexuality, family structures and identity politics. Questions of Jewish memory, transgenerational haunting, epigenetics and contemporary discourses of intersectionality are fundamental to its exploration of the shifting sands of subjectivity. As such, it is part of a new wave of cultural representation that continues to redefine the parameters of both gender and Jewish studies.

Transparent, with its sustained exploration of intersectionality reminds us that the ways in which we conceptualise identities is a matter of ongoing negotiation. As Ann Pellegrini pointed out in 1997, these are still complex and often rather fraught matters:

Attention to the ways in which axes of difference may mutually inform, cross, and contradict one another is among the energizing concerns of much recent feminist, queer, and postcolonial theories. But what does it mean, in critical practice and not simply as a theoretical piety, to attend to and historicize the interarticulations...of sexual and racial difference? Among other things, it means not taking gender, race, and sexuality for granted as categories for analysis or even categories of experience. ${ }^{16}$

As gender studies continues to evolve, and Jewishness is increasingly part of that field of enquiry, literary and cultural critics, as well as other academics within the humanities and beyond, need to be alert to such interarticulations. This is, I would argue, where both the challenges and the possibilities for the future of gender and Jewish studies reside.

\footnotetext{
${ }^{12}$ Francesca Segal, The Innocents (London: Chatto and Windus, 2012); Eve Harris, The Marrying of Chani Kaufman (Dingwall: Sandstone Books, 2013)

${ }^{13}$ For an overview of the field see, Sarah Lightman, ed., Graphic Details: Jewish Women's Confessional Comics in Essays and Interviews (Jefferson: McFarland \& Co, 2014).

${ }^{14}$ Jill Soloway, Transparent, Amazon Prime 2014-2016.

${ }^{15}$ Hadley Freeman, "Transparent's Jill Soloway: 'The words male and female describe who we used to be," Guardian, 21 May 2017. Accessed online at: https://www.theguardian.com/tv-and-radio/2017/may/21/transparents-jill-soloway-the-words-male-andfemale-describe-who-we-used-to-be

${ }^{16}$ Ann Pellegrini, "Interarticulations: Gender, Race, and the Jewish Woman Question," in Miriam Perkowitz and Laura Levitt, eds., Judaism since Gender (Abingdon: Routledge, 1997), 49.
} 


\section{BIBLIOGRAPHY}

Alderman, Naomi. Disobedience. London: Viking, 2006.

Boyarin, Daniel. Unheroic Conduct: the Rise of Heterosexuality and the Invention of the Jewish Man. Berkeley: University of California Press, 1997.

Boyarin, Daniel, Daniel Itzkovitz and Ann Pellegrini, eds. Queer Theory and the Jewish Question. New York: Columbia UP, 2003.

Brod, Harry, ed. A Mensch Among Men: Explorations in Jewish Masculinity. Freedom: Crossing Press, 1988.

Brod, Harry, and Rabbi Shaw Israel Zevit, eds. Brother Keepers: New Perspectives on Jewish Masculinity. Harriman: Men's Studies Press, 2010.

Butler, Judith. Gender Trouble. London: Routledge, 1990.

Butler, Judith. Bodies That Matter. London: Routledge, 1993.

Cheyette, Bryan. Between 'Race' and Culture: Representations of 'The Jew'. Stanford: Stanford UP, 1996.

Cheyette, Bryan. Constructions of 'The Jew' in English Literature and Society. Cambridge: CUP, 1993.

Freeman, Hadley. "Transparent's Jill Soloway: 'The words male and female describe who we used to be,” Guardian, 21 May 2017. Accessed online at: https://www.theguardian.com/tv-andradio/2017/may/21/transparents-jill-soloway-the-words-male-and-female-describe-who-weused-to-be

Gilman, Sander. The Jew's Body. Abingdon: Routledge, 1992.

Harris, Eve. The Marrying of Chani Kaufman. Dingwall: Sandstone Books, 2013.

Lightman, Sarah, ed. Graphic Details:Jewish Women's Confessional Comics in Essays and Interviews. Jefferson: McFarland \& Co, 2014.

Pellegrini, Ann. "Interarticulations: Gender, Race, and the Jewish Woman Question,” in Miriam Perkowitz and Laura Levitt, eds., Judaism since Gender. Abingdon: Routledge, 1997.

Presner, Todd. Muscular Judaism: the Jewish Body and the Politics of Regeneration. London: Routledge, 2007.

Sedgwick, Eve Kosofsky. Between Men. New York: Columbia, 1985.

Sedgwick, Eve Kosofsky. Epistemology of the Closet. Berkeley: University of California Press, 1990.

Sedgwick, Eve Kosofsky. Tendencies. London: Routledge, 1994.

Segal, Francesca. The Innocents. London: Chatto and Windus, 2012.

Shapiro, James. Shakespeare and the Jews. New York: Colombia University Press, 1996.

Soloway, Jill. Transparent. Amazon Prime, 2014-2016. 